\title{
Índios e africanos livres nas obras públicas, Manaus, século XIX
}

\author{
Indigenous people and Free Africans in Public Works, Manaus, 19 ${ }^{\text {Th }}$
}

\section{Patrícia Melo*}

Resumo: Este artigo se propõe a lançar luz sobre as trajetórias e as relações entre africanos livres e índios na Manaus do século XIX, dando ênfase ao compartilhamento de experiências em espaços sociais marcados pela multietnicidade e pela existência de fronteiras nebulosas entre a liberdade e a escravidão nesse mundo do trabalho não livre.

Palavras-chave: Africanos livres; índios; obras públicas; Amazônia.

Abstract: This article aims to analyse the relations between free Africans and Indians in 19th century Manaus, emphasizing their experiences shared in social spaces who were marked by multiethnicity and blurred boundaries between freedom and slavery in this world of nonfree labour.

Keywords: Free africans; indians; public works; Amazon.

- RA 1859. Outra vez chegara o tempo das chuvas onde só se escutava a voz das águas - a fazer crescer correntezas e encharcar a mata dos arrabaldes, os terrenos baldios e as ruas precárias. A cidade, cortada por vários igarapés, sabia que suas pontes, sempre inseguras, estavam sob risco permanente naquele período do ano em que águas do céu e da terra formavam uma coisa só.

Dias assim estavam se tornando familiares para Joaquim José Laudelino dos Santos Cabinda. Afinal, ele desembarcara nessa estranha cidade em abril de 1855, trazido do Rio de Janeiro e, quando chegaram os Finados, viu como o céu desabava sobre a cidade. Aquele foi o primeiro de seus muitos invernos nos confins do Império. ${ }^{1}$

* Doutora em História pela Universidade Federal Fluminense (UFF). Professora Titular do Departamento de História da Universidade Federal do Amazonas (UFAM). ORCID: https://orcid.org/0000-0003-3160-1258.

E-mail: patriciammelo6@gmail.com.

1 Arquivo Nacional - AN, Série Justiça, IJ6, pasta 220 (maio-ago. 1855). 
Laudelino, africano livre, pedreiro, sabia bem o trabalho adicional que teriam na olaria onde era empregado. Estava ele em Manaus, capital da província do Amazonas, para onde tinha sido enviado pelo governo imperial junto com outros seus iguais, todos eles pertencentes à categoria especialmente criada para designar aqueles que eram parte dos carregamentos dos navios apanhados no tráfico ilegal a partir de 1831. Já que não podiam ser considerados escravos, eram colocados sob a tutela do Estado brasileiro por um período definido, podendo ser entregues a particulares ou enviados a prestar serviço em instituições públicas. Finda a tutela, o Estado ainda Ihes regulava a vida e podia arbitrar-Ihes novos destinos. Foi assim que, gradativamente, cerca de cem africanos livres chegaram ao Amazonas a partir de 1854 . Laudelino era um deles. ${ }^{2}$

Entre 1850 e 1870, período em que se desenrola parte da vida de nossos personagens, Manaus passava por mudanças. A criação da província (1850) impactou a vida da modesta cidade por conta da abertura de muitas obras públicas, tais como a construção e reforma de pontes e prédios, aterro de igarapés, abertura e calçamento de ruas. Em atendimento à recorrente queixa das autoridades quanto à falta de braços especializados, os africanos foram enviados pelo governo imperial. Chegaram oleiros, pedreiros e carpinteiros e, desse modo, a olaria foi o primeiro pouso dos africanos na cidade.

O trabalho na olaria provincial, criada em 1853 às margens do igarapé de Manaus, era realizado por homens, mulheres e crianças. Ali, engajados na fabricação das telhas, tijolos e potes, achavam-se indígenas de diferentes etnias recrutadas para o serviço público e particular por meio dos diretores de índios, responsáveis pela execução do Regulamento das Missões (1845), a legislação indigenista do Império. ${ }^{3}$ Com eles conviviam os africanos que conduziam as atividades na olaria e eram responsáveis pelo treinamento dos índios. Assim, a olaria e suas oficinas anexas (serraria, carpintaria e ferraria) formavam um espaço multiétnico de trabalho e de moradia. À medida em que chegavam mais trabalhadores indígenas e/ou africanos, eles iam sendo distribuídos para atender às frequentes demandas das obras públicas e particulares, formando, tal como na olaria, turmas de trabalho multiétnicas espalhadas pela cidade. ${ }^{4}$

2 Para abordar o tema dos africanos livres no Brasil, é indispensável recorrer ao alentado trabalho de MAMIGONIAN, Beatriz G. Africanos livres. A abolição do tráfico de escravos no Brasil. São Paulo: Companhia das Letras, 2017. A bibliografia sobre os africanos livres no Brasil é crescente. Além do trabalho essencial de Beatriz Mamigonian, sugerimos, entre outros: ARAÚJO, Carlos Eduardo M. Cárceres imperiais: a Casa de Correção do Rio de Janeiro: seus detentos e o sistema prisional no Império, 1830-1861. Tese (Doutorado em História) Unicamp, Campinas, 2009; SANTOS, Nilton Pereira dos. A fábrica de ferro São João de Ipanema: economia e política nas últimas décadas do Segundo Reinado (1860-1889). Tese (Doutorado em História) - Universidade de São Paulo, São Paulo, 2009; BERTIN, Enidelce. Os meia-cara: africanos livres em São Paulo no século XIX. Tese (Doutorado em História) - Universidade de São Paulo, São Paulo, 2006; MOREIRA, Aline. Liberdade tutelada: os africanos livres e as relações de trabalho na Fábrica de Pólvora da Estrela, Serra da Estrela/RJ (c.1831-c.1870) Dissertação (Mestrado em História) - Unicamp, Campinas, 2005; FLORENCE, Afonso. Entre o cativeiro e a emancipação: a liberdade dos africanos livres no Brasil. Dissertação (Mestrado em História) Universidade Federal da Bahia, Salvador, 2002; SOUSA, Jorge L. Prata. Africano livre ficando livre: trabalho, cotidiano e luta. Tese (Doutorado em História) - Universidade de São Paulo, São Paulo, 1999.

3 Em se tratando da política indigenista do império, ver: SAMPAIO, Patrícia Melo. Política indigenista no Brasil Imperial. In: GRINBERG, Keila; SALLES, Ricardo (org.). O Brasil Imperial. Volume I - 1808-1831. Rio de Janeiro: Civilização Brasileira, 2009. p. 175-205.

4 Ver: SAMPAIO, Patrícia Melo. Nos confins do Império: diversidade e etnicidade no mundo do trabalho na Amazônia do século XIX. In: XAVIER, Giovana (org.). Histórias da escravidão e do pós-abolição para as 
Beatriz Mamigonian tem estudado, com acurácia, a condição dos africanos livres, dimensionando seu impacto no contexto de uma sociedade escravista como era o Brasil no século XIX. Como apontou a autora, existiam os "africanos livres", algo em torno de 11.000 indivíduos, e o imenso contingente de "africanos ilegalmente escravizados" sobre o qual se assentou a reprodução de toda a economia brasileira até o final do século XIX. Estavam espalhados por diferentes pontos do país e inseridos no diversificado mundo do trabalho do Brasil escravista. Em se tratando de africanos livres, há que se notar diferenças substantivas depois de 1850. Já existem africanos emancipados, isto é, aqueles que, passados 14 anos, já haviam recebido suas cartas de emancipação e foram obrigados a se reestabelecer em lugares distintos daqueles onde haviam completado o tempo de trabalho. Esse foi o caso da maioria dos que foram enviados pelo governo imperial para viver na província do Amazonas. ${ }^{5}$

Tomando como ponto de partida essa diversidade no mundo do trabalho urbano de Manaus, este artigo se propõe a lançar luz sobre as trajetórias e as relações entre africanos livres e índios, dando ênfase ao compartilhamento de experiências em espaços sociais marcados pela multietnicidade e pela existência de fronteiras nebulosas entre a liberdade e a escravidão nesse mundo do trabalho não livre.

\section{Uma cidade "em obras"}

A CRIAÇÃo E IMPLANTAÇÃo da província do Amazonas, entre os anos de 1850 e 1852, deixou suas marcas no espaço urbano da capital. É importante lembrar que esses anos iniciais da organização administrativa e política da nova capital do império também têm sua importância na compreensão das múltiplas transformações pelas quais a capital do Amazonas passou ao longo do século XIX. A rigor, a historiografia tem dado bastante atenção às intervenções ocorridas ali nas décadas finais do século XIX, durante a chamada belle époque ${ }^{6}$ contudo, os dados disponíveis apontam para a anterioridade desses processos de intervenção na malha urbana, ainda que não se possa perder de vista as especificidades que guardarão esses diferentes períodos de mudança. É da conjuntura que se seguiu à implantação da província que trataremos aqui. As possibilidades de acompanhamento do destino de nossos personagens não se estendem muito para além da década de 1860, como já demonstraremos.

Manaus, no início da segunda metade do século XIX, é cidade de números modestos quando comparada com outras que ocupavam posição similar. Elevada à categoria de cidade em 1848, experimentou, nesse momento, várias intervenções no espaço urbano, como a construção de prédios e a abertura de muitas frentes de trabalho, de modo particular, nas obras públicas: aterros de igarapés, construção e reforma de pontes, calçamentos, abertura de ruas,

escolas. Belo Horizonte: Fino Traço Editora; Rio de Janeiro: MC\&G Editorial; Brasília: MEC, 2015. p.179-194.

5 MAMIGONIAN, Beatriz. O direito de ser africano livre. In: LARA, Silvia H.; MENDONÇA, Joseli Maria N. (org.).

Direitos e justiças no Brasil: ensaios de História Social. Campinas: Editora da Unicamp, 2006. p. 129-160.

6 Uma referência obrigatória para os estudos do período é: DIAS, Edinea Mascarenhas. A ilusão do fausto: Manaus - 1890-1920. $2^{\mathrm{a}}$ ed. Manaus: Editora Valer, 2007. 
entre outras. Além disso, havia a crescente chegada de novos contingentes populacionais ao espaço do município que possuía, em 1852, uma população estimada em 5.092 indivíduos e que, em 1872, alcançou as 17.686 almas. $^{7}$

Havia muito a fazer na nova capital, mas uma queixa recorrente dos administradores públicos era, exatamente, a falta de trabalhadores especializados para dar conta de tantas frentes. Os africanos livres foram enviados para oAmazonas em decorrência das determinações da nova conjuntura de gestão dos africanos pelo Ministério da Justiça e para atender aos insistentes clamores dos administradores provinciais por mão de obra para a província. Nesse novo local de residência e trabalho, os africanos, mesmo emancipados, eram colocados sob vigilância permanente e cabia ao governo da província designar-lhes postos de trabalho. ${ }^{8}$

Uma demanda recorrente era a instalação da olaria para solucionar a crônica ausência de tijolos e telhas. Tratava-se de uma reclamação antiga que, não por acaso, constituiu-se na prioridade do governo provincial recém-instalado. Já em 1853, o presidente da província Herculano Ferreira Penna anunciava à Assembleia Legislativa sua decisão de criar uma olaria provincial para produzir telhas e tijolos. Suas justificativas eram mais que razoáveis: a notável expansão das obras públicas e particulares; os altos custos do frete desses materiais de Belém para Manaus; a incapacidade de atendimento da demanda pelas modestas olarias existentes; a disponibilidade de matéria-prima nas imediações da cidade; e, por fim, a expectativa de economia de "dinheiros públicos destinados às obras". 9

Para atender a essa demanda específica, em 1854, o governo imperial colocou à disposição da província para serem empregados nos "trabalhos da olaria, quatro africanos livres", um condenado à prisão com trabalho que era oficial de oleiro e mais "dois africanos, sendo um carpinteiro e o pedreiro". ${ }^{10}$ A olaria vai se tornar um importante espaço de convivência e de trocas de experiências. Para começar, para lá se destinaram os primeiros grupos de africanos livres que chegaram à província em 1854 e 1855. Ao todo, são cerca de 18 pessoas, entre homens, mulheres e crianças, que irão ser alocados na nova olaria e lá residirão por quase uma década. Além disso, ela também era destino dos indígenas recrutados regularmente para o trabalho nas obras públicas da cidade. Para ser mais exato, como bem reconhecia o presidente da província em 1854, na cidade, "quase todos os trabalhadores são índios do Alto Rio Negro". 11

7 SAMPAIO, Patrícia Melo. Os fios de Ariadne. Fortunas e hierarquias sociais na Amazônia, século XIX. São Paulo: Editora Livraria da Física, 2014. p. 171-175.

8 MAMIGONIAN, op. cit., p. 345-346. A historiografia local ainda carece de leituras mais ampliadas quanto ao tema porque tem se concentrado ainda na leitura de determinadas categorias profissionais. Contudo, quanto à presença e o lugar dos trabalhadores escravizados no mercado de trabalho de Manaus nesse período, vale conferir: COSTA, Jéssyka Samya Ladislau. Por todos os cantos da cidade: escravos negros no mundo do trabalho na Manaus oitocentista. Dissertação (Mestrado em História) - Universidade Federal Fluminense, Niterói, 2016.

9 AMAZONAS. Fala dirigida à Assembleia Legislativa Provincial do Amazonas no dia $1^{\circ}$ de outubro de 1853, em que se abriu a sua $2^{a}$ sessão ordinária pelo presidente da província, conselheiro Herculano Ferreira Penna. (Nota da autora: falas, exposições e relatórios aqui utilizados estão disponíveis on-line em http://ddsnext.crl. edu/titles/164\#?c=4\&m=0\&s=0\&cv=0\&r=0\&xywh=-1511\%2C-176\%2C4988\%2C3518).

10 Estrella do Amazonas, Manaus, p. 1, n. 88, 4 maio 1854.

11 AMAZONAS. Fala dirigida à Assembleia Legislativa Provincial do Amazonas em 1 de agosto de 1854, em que 
Em março de 1855, todos os africanos livres recém-chegados já estavam engajados nas obras públicas sob os olhares de três feitores. Estavam lá na olaria: além de um pedreiro e um oleiro, contavam-se 19 índios e sete africanos livres que eram: Francisco José Caldeira, Gualberto, Manoel Benguela, Teófilo Congo, Domingos Mina, Francisco Benguela e José Joaquim Lopes Moçambique. ${ }^{12}$

Em 1856, o número de africanos na lida da olaria aumentou. Sob a direção do capitão Joaquim Isidoro de Oliveira ali trabalhavam um administrador e dois feitores, três carpinteiros, um pedreiro, 12 índios e mais 12 africanos livres, entre homens (8) e mulheres (4). José Laudelino Cabinda era um deles. A essa altura, eles já haviam dado conta da construção que serviria tanto de casa para os feitores quanto para depósito de material e, considerando que a olaria ficava do outro lado do igarapé dos Remédios, construíram uma pequena ponte provisória para deixar de depender da "má vontade" dos proprietários das canoas que faziam a travessia. ${ }^{13}$

A olaria era o principal ponto de distribuição dos africanos livres pelas obras públicas da cidade e, progressivamente, eles vão se tornando trabalhadores imprescindíveis, não apenas ali, mas em todas as obras da cidade, a despeito de sua "má fama" de "ébrios, rixosos e madraços". Em pouco tempo, veremos que os africanos livres bem como os índios recrutados nas diretorias parciais ficariam sob a alçada do diretor da Repartição de Obras Públicas e, desse modo, cabia-Ihe, com frequência, o poder discricionário de redistribuir os trabalhadores indígenas e africanos. ${ }^{14}$

Entre setembro de 1858 a abril de 1859, a Repartição de Obras Públicas controlou o fluxo de mais de 288 índios sendo que a maioria (53\%) deles foi destinada para as diversas obras públicas, destes 21 desertaram e 22 foram colocados a serviço particular. ${ }^{15} \mathrm{O}$ diretor da repartição também possuía determinadas prerrogativas quanto à concessão de abonos salariais aos operários mais morigerados e ainda lhe cabia providenciar as rações de sustento dos trabalhadores, além de vestimentas para os índios. Punições e castigos também entravam nessas contas, como é o caso da responsabilidade de fazer dar busca policial em encalço dos índios que abandonavam o serviço antes do prazo acordado. ${ }^{16}$

se abriu a sua $3^{a}$ sessão ordinária pelo presidente da província, conselheiro Herculano Ferreira Pena.

12 Estrella do Amazonas, Manaus, p. 4, n. 88, 4 maio 1854.

13 Estrella do Amazonas, n. 116/117, p. 9, 21 jul. 1855 e n. 168, 6 set. 1856 e AMAZONAS. Fala dirigida à Assembleia Legislativa Provincial do Amazonas no dia 3 de maio de 1855 , em que se abriu a sua $4^{a}$ sessão ordinária pelo vice-presidente da província Dr. Manoel Gomes Correa de Miranda.

14 AMAZONAS. Exposição feita ao Exm. ${ }^{\circ}$ Sr. Presidente da Província do Amazonas, João Pedro Dias Vieira, pelo $1^{\circ}$ vice-presidente da província por ocasião de passar-lhe a administração em 28 de janeiro de 1856, p. 15; e AMAZONAS. Exposição feita ao Exm. ${ }^{\circ} 1^{\circ}$ Vice-presidente da Província do Amazonas Dr. Manoel Gomes Correa de Miranda pelo presidente João Pedro Dias Vieira por ocasião de passar-Ihe a administração em 26 de fevereiro de 1857, anexo I, p. 11. O controle da Repartição de Obras Públicas sobre os africanos livres se estendeu até aqueles que estavam sob a tutela da Companhia de Navegação e Comércio do Amazonas. Ainda que trabalhassem na Companhia, foram, por ordem judicial, matriculados nas Obras Públicas. Cf. Estrella do Amazonas, p. 2. n. 495, 3 nov. 1860. Sobre o funcionamento das diretorias criadas na província sob a égide do regulamento de 1845, ver: MACIEL, Benedito do Espírito Santo. Histórias intercruzadas: projetos, ações e práticas indígenas e indigenistas na Província do Amazonas (1850-1889). Tese (Doutorado em Sociedade e Cultura na Amazônia) - Universidade Federal do Amazonas, Manaus, 2015.

15 AMAZONAS. Fala dirigida à Assembleia Legislativa Provincial em $1^{\circ}$ de outubro de 1857 pelo presidente da província Dr. Ângelo Thomaz do Amaral, anexo V, p. 4.

16 Estrella do Amazonas, n. 322, 25 set. 1858 e n. 690, 19 nov. 1862. 
As frentes de trabalho cresciam: a construção e o reparo das pontes, a reedificação do quartel do Pelourinho e do Hospital Militar, o preparo do cemitério dos Remédios, além do corte e da condução de madeiras, ainda havia uma obra grandiosa em curso situada na mais extensa rua da cidade: a da Igreja Matriz, localizada na rua Brasileira. Estreita, irregular e cortada por cinco igarapés, a rua Brasileira era a única via que cruzava a cidade no sentido Leste-Oeste e ainda era local de edifícios imponentes como é caso da matriz dedicada a Nossa Senhora da Conceição, considerada como "a primeira grande obra arquitetônica construída na cidade e a mais importante do período provincial". ${ }^{17}$

\section{Imagem 1 - Matriz e arrabaldes}

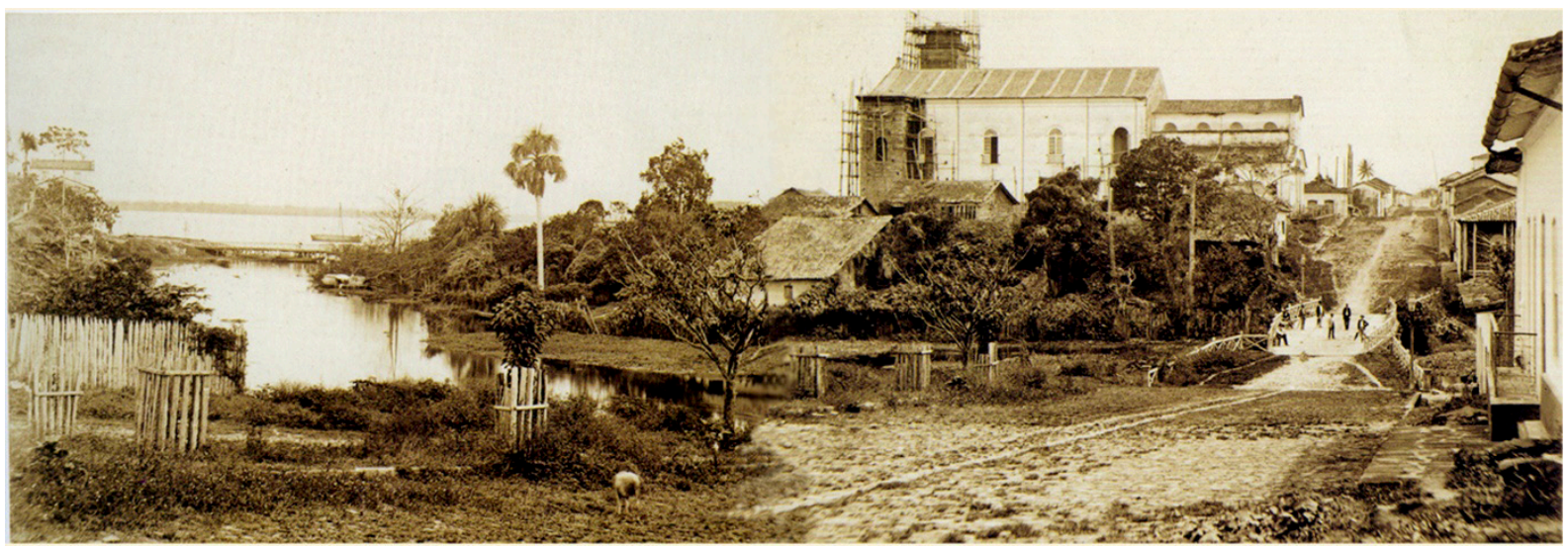

Igarapé do Espírito Santo, construção da igreja matriz e a ponte do Espírito Santo. Paisagem panorâmica resultante da junção de duas fotografias localizadas em álbum do acervo da Biblioteca Pública do Amazonas (770.811). Acervo particular do Prof. Dr. Otoni Mesquita.

Perdida em um incêndio em 1850, a reconstrução da igreja se estenderia por quase duas décadas. Ao seu lado corria o igarapé do Espírito Santo onde estava a ponte do mesmo nome, a mais próxima do imenso canteiro de obras que era o sítio da catedral até sua reinauguração em 1878. Importante lembrar que os trabalhadores da olaria tinham que atravessar o igarapé de Manaus para trazer as telhas e tijolos para a matriz, enquanto outros estavam ali ocupados fazendo com que a rua Brasileira e adjacências fosse um espaço de intensa circulação de africanos e índios. Em 1862, só para a obra da matriz foram designados mais de 30 africanos livres. ${ }^{18}$

Em sua dissertação, Ana Paula Rabelo recuperou, entre outras questões relevantes, as inúmeras dificuldades experimentadas com o andamento das obras na matriz, e a falta de índios era a mais frequente. Em um desses momentos, as escusas do diretor interino da Repartição de Obras Públicas alcançavam todas as obras da cidade por conta da falta de pedra e também de "pedreiros idôneos": apesar do lamento, a dificuldade estava superada

17 MESQUITA, Otoni. Manaus: história e arquitetura (1852-1910). $3^{\mathrm{a}}$ ed. Manaus: Editora Valer, 2006. p. 69. Agradeço ao professor Otoni Mesquita a extrema gentileza em ceder a imagem da matriz aqui utilizada.

18 AMAZONAS. Relatório que à Assembleia Legislativa Provincial do Amazonas apresentou ao Sr. Manoel Clementino Carneiro da Cunha na abertura da sessão ordinária de 3 de maio de 1862. p. 20. 
porque com o recurso para o trabalho de uma turma extra de índios foi possível garantir o abastecimento necessário. ${ }^{19}$

Como vimos, a manutenção das pontes era um serviço essencial e a do igarapé do Espírito Santo era das mais urgentes por conta da relevância da via. Para seu reparo, seriam designados aqueles índios e africanos que, desde 1855, vinham se aperfeiçoando nos ofícios de pedreiro e carpina no espaço da olaria; e a obra que "a princípio era defeituosa e grosseira pela imperícia dos operários (...) se foi aperfeiçoando a ponto de se tornar irrepreensível". Quando a reforma da ponte terminou, em 1857, o presidente Manoel de Miranda garantiu que tinha sido uma "excelente escola para os operários da província". ${ }^{20}$

A lista de obras na cidade não parava de aumentar entre 1857-1859: os reparos na enfermaria do Hospital Militar, na ponte de São Vicente, dos Remédios e do Palácio, a construção de uma torre na ermida de Nossa Senhora dos Remédios, a abertura da estrada para o Rio Branco, o avanço nos alicerces do estabelecimento dos Educandos Artífices e nos trabalhos para o cemitério da Cachoeira Grande (São José). A olaria, embora tenha fechado seus fornos em 1858, continuou a ser local de trabalho apenas nas suas oficinas anexas de carpintaria, ferraria e serraria, sendo ainda espaço essencial para fabricação de canoas e de reparos para embarcações maiores. Em meio à azáfama da construção do novo estabelecimento dos Educandos, estavam as casas dos africanos livres que ainda lá moravam (e trabalhavam). ${ }^{21}$

\section{Os trabalhadores na cidade: vivências e resistências}

A OLARIA E SUAS OFICINAS anexas era um extraordinário espaço de trocas e experiências. De um lado, os africanos livres ali habitavam de modo permanente e estavam à frente de trabalhos mais especializados. Desse modo, funcionavam como mestres para os índios que se alternavam em turma a cada dois meses. De outro lado, é importante lembrar que estamos lidando com grupos multiétnicos e a questão da língua deve ter sido um ponto muito relevante a considerar na construção dessas experiências como trabalhadores engajados nas obras públicas. Os africanos, em sua maior parte, já eram emancipados quando chegados ao Amazonas ainda que compartilhassem de uma origem majoritária de regiões da África central atlântica.

Sua condição de emancipados indica uma permanência de mais de uma década no Brasil e, portanto, aponta para o conhecimento da língua portuguesa. Laudelino era emancipado.

19 RABELO, Ana Paula de Souza. De templo de taipa a templo de pedra. A construção da igreja matriz de Manaus (1852-1878). Dissertação (Mestrado em História) - Universidade Federal do Amazonas, Manaus, 2008. p. 50-52, passim.

20 AMAZONAS. Exposição feita ao Exm. ${ }^{\circ} 1^{\circ}$ Vice-presidente da Província do Amazonas Dr. Manoel Gomes Correa de Miranda pelo presidente João Pedro Dias Vieira, por ocasião de passar-lhe a administração em 26 de fevereiro de 1857, anexo I, p. 2.

21 Sobre a experiência de alguns africanos livres no âmbito do estabelecimento dos Educandos Artífices, ver: SAMPAIO, Patrícia Melo. Educação, trabalho e diversidade étnica: Educandos Artífices e africanos livres na Amazônia, século XIX. In: COELHO, Wilma B.; COELHO, Mauro C. (org.) Trajetórias da diversidade na educação: formação, patrimônio e identidade. São Paulo: Editora Livraria da Física, 2012. p. 19-50. 
Contudo, na convivência com os índios de diferentes grupos linguísticos em Manaus, é mais provável que, rapidamente, tenha aprendido o nheengatu, a língua geral amazônica, conhecida como a língua do mundo do trabalho. Como bem sublinhou Carlos Araújo, quando tratou da situação dos africanos nas obras públicas do Rio de Janeiro oitocentista: "A proximidade deles com as outras categorias de trabalhadores ajudaram a ladinizar aqueles africanos. Aprenderam a língua, a cultura local e o funcionamento do complexo e intrincado mundo da escravidão". ${ }^{22}$

Nas obras da matriz e em muitos outros canteiros, registrar-se-iam muitos desacertos. As frequentes fugas dos índios fizeram com que fossem caçados pela polícia e suas lideranças cobradas para que os reconduzissem à cidade, caso chegassem às aldeias. Por seu turno, os africanos foram protagonistas de mil disputas incluindo agressões físicas aos feitores, demandas por pagamento porque ganhavam menos que os livres, somadas à embriaguez que, frequentemente, os levava à cadeia.

Acrescente-se a isso o fato de os africanos estarem sujeitos ao toque de recolher, cabendo aos chefes de polícia expedir as ordens para deter, por uma noite, os africanos que fossem encontrados nas ruas depois das oito horas da noite e, no dia seguinte, "deverão ser apresentados ao diretor das obras públicas para serem empregados no serviço". ${ }^{23}$

Também são acusados de desvio de materiais do canteiro e ainda de "fazer cera" durante o serviço. Aliás, $35 \%$ das prisões dos africanos livres eram por conflitos nos locais de trabalho, e foi assim que Domingos Mina foi preso em 1858 por ameaças ao feitor da obra do cemitério São José. Geraldo da Silva e Apolinário Angola foram parar na cadeia juntos várias vezes para "correção", a pedido do diretor das Obras Públicas.

Índios e africanos estavam juntos no mundo do trabalho e, além de espaços de moradia e confraternização, das rações de farinha e peixe, compartilharam castigos e punições. O Quadro 1, que recupera o movimento das prisões em Manaus entre 1854 e 1870, ilumina uma faceta importante desse cotidiano. Acompanhando os motivos de entrada na prisão, verificamos que africanos eram assíduos na precária cadeia local: grosso modo, de cada 10 prisões, quatro eram de africanos livres (48\%), e eles respondem por $55 \%$ das prisões por embriaguez e $68 \%$ das decorrentes de brigas.

22 ARAÚJO, Carlos Eduardo Moreira. Arquitetando a liberdade: os africanos livres e as obras públicas no Rio de Janeiro imperial. História Unisinos, São Leopoldo, v. 14, n. 3, p. 330, 2010. Sobre o nheengatu, ver, particularmente: FREIRE, José R. Bessa. Rio Babel: a história das línguas na Amazônia. Rio de Janeiro: EDUERJ, 2011.

23 Estrella do Amazonas, Manaus, n. 589, 26 out. 1861. 
Quadro 1 - Motivo das prisões por condição jurídica e cor - Manaus (1854-1870)

\begin{tabular}{|c|c|c|c|c|c|c|c|c|c|c|c|}
\hline \multirow{2}{*}{$\begin{array}{c}\text { Motivo } \\
\text { da prisão }\end{array}$} & \multicolumn{9}{|c|}{ Livres } & \multirow{2}{*}{ Escravos } & \multirow{2}{*}{ Total } \\
\hline & Branco & Gentio & Índio & Tapuio & Forro & $\begin{array}{c}\text { Africano } \\
\text { livre }\end{array}$ & Menor & Educando & Total & & \\
\hline Embriaguez & 3 & & 18 & 35 & 1 & 85 & 1 & 1 & 144 & 9 & 153 \\
\hline À requisição & & & & & & 27 & 1 & & 28 & 42 & 70 \\
\hline Correção & & & & & & 29 & & & 29 & 10 & 39 \\
\hline Briga & & & 1 & 4 & & 15 & & & 20 & 2 & 22 \\
\hline Averiguações & 2 & & & 8 & & 9 & & & 19 & 1 & 20 \\
\hline Andar fugido & & & & & & & & & - & 16 & 16 \\
\hline $\begin{array}{l}\text { Crimes contra a } \\
\text { seg. ind. e prop. } \\
\text { privada }\end{array}$ & 2 & 1 & 1 & 7 & & 3 & 1 & & 14 & 1 & 15 \\
\hline Indagações & & & 1 & 4 & & 3 & & & 8 & 2 & 10 \\
\hline Ferimentos & 1 & & & 1 & & 5 & & & 7 & & 7 \\
\hline Ameaças & & & & 2 & & & & 4 & 6 & & 6 \\
\hline $\begin{array}{c}\text { Desordem e } \\
\text { desobediência }\end{array}$ & & & & 2 & & 2 & & & 4 & & 4 \\
\hline $\begin{array}{c}\text { Acoitamento de } \\
\text { escravos }\end{array}$ & & & 1 & & & 2 & & & 3 & & 3 \\
\hline Insultos & & & & & & & 1 & & 1 & 2 & 3 \\
\hline Outros crimes & & & & & & 2 & & & 2 & 1 & 3 \\
\hline $\begin{array}{l}\text { Andar fora de } \\
\text { hora }\end{array}$ & & & & & & & & & - & 2 & 2 \\
\hline Indiciamento & & & & 1 & & & & & 1 & 1 & 2 \\
\hline $\begin{array}{l}\text { Infração de } \\
\text { posturas }\end{array}$ & & & & 2 & & & & & 2 & & 2 \\
\hline Total & 8 & 1 & 21 & 66 & 1 & 182 & 4 & 5 & 288 & 89 & 377 \\
\hline
\end{tabular}

Fonte: Extratos policiais dos jornais Estrella do Amazonas (1854-1863); O Catechista (1862-1871); A Voz do Amazonas (1866-1867); Jornal do Rio Negro (1867-1868); Correio de Manáos (1869) e o Comércio do Amazonas (1870). (Elaborada por Ygor Rocha Cavalcante)

Outros motivos também dizem algo sobre sua mobilidade na cidade e as tensões no ambiente de trabalho: as prisões efetuadas por "requisição", "correção", "averiguação", "indagação" e "desordem e desobediência" somam 70 (35\%) ocorrências. Comparando esses mesmos motivos aplicados aos escravos, o resultado é surpreendente porque, entre eles, essas mesmas ocorrências não passam de 14\% (55). Não há equívoco em afirmar que africanos livres possuíam menor mobilidade que escravos e que estavam sob monitoramento muito mais rigoroso que estes. Isso só chama nossa atenção para a existência de fronteiras muito fluidas que distinguiam sua condição de liberdade precária daquela experimentada no mundo da escravidão. ${ }^{24}$

$\overline{24}$ O conceito de liberdade precária a que recorremos está em: CHALHOUB, Sidney. A força da escravidão: 
Olhando os números dos índios, em suas diversas categorias (gentios/tapuios/índios), vemos que dividem com os escravos o mesmo percentual de $23 \%$ do total de detenções. Contudo, seus motivos são diferentes. Eles são detidos por embriaguez (34\%) com maior frequência que os escravos $(0,05 \%)$. Contudo, vemos que outro motivo frequente de suas detenções dizia respeito às mesmas categorias de restrição de mobilidade que alcançaram os africanos, ainda que não com a mesma intensidade nesse caso. Suas ocorrências para "averiguação", "indagação" e "desordem e desobediência" somaram 14 (0,03\%), ou seja, de acordo com os dados desse mapa, o controle sobre os índios, cidadãos livres, era 100 vezes menor do que o que se exercia sobre os africanos livres.

O Quadro 1 tem lá suas lacunas com relação ao controle efetivo sobre as movimentações dos índios e que devemos nuançar aqui. Não há registro regular sobre suas prisões quando deixavam, sem permissão, seus locais de trabalho. As fontes são abundantes ao demonstrar o quanto isso era frequente. Senão vejamos, os índios recrutados por meio dos diretores, com a intermediação de suas lideranças indígenas (Principais) ${ }^{25}$ também eram alvo do controle do Estado porque, ainda que contratos de trabalho tivessem sido firmados nos termos do Regulamento das Missões, eles se evadiam com frequência das obras públicas e seus principais eram chamados às falas pelas autoridades provinciais reclamando a devolução dos fugitivos.

Esses foram os casos dos principais da aldeia do Manaquiri e de Manacapuru, próximas a Manaus, para que não aceitassem o retorno de índios aos seus respectivos aldeamentos sem que apresentassem a guia de sua liberação do serviço assinada pelo diretor das Obras Públicas, como estava acontecendo. Esses casos nos fazem chamar a atenção para uma certa leniência da liderança indígena em receber os engajados de suas aldeias de volta, "ignorando" certos detalhes da burocracia de dispensa formal. Os ofícios cobram o compromisso dos principais com a permanência dos trabalhadores indígenas e, eventualmente, ameaçam-nos com outras sanções. Os índios, às vezes, sequer chegavam à capital. Esse foi o caso do grupo engajado com João Guedes, vindo de Canumã, que se apresentou sozinho às obras públicas sendo que, no documento que o encaminhava, havia mais cinco junto com ele, a essa altura, evadidos. $\mathrm{O}$ diretor da aldeia foi chamado à responsabilidade para fazer retornar os desaparecidos assim que aparecessem em suas casas. ${ }^{26}$

As razões para as retiradas sistemáticas dos índios são muitas, mas, destacamos aquelas mais citadas na documentação. Dentre elas, a violência do recrutamento, o atraso no pagamento dos salários, maus-tratos e, especialmente, o descumprimento do tempo de trabalho contratado que, a princípio, era de dois meses. A extensão unilateral do tempo de permanência na cidade gerava imensa insatisfação e era justificativa suficiente para uma fuga que, nada mais era, de que um retorno às suas comunidades de origem. Por outro lado,

ilegalidade e costume no Brasil escravista. São Paulo: Companhia das Letras, 2012.

25 Estrella do Amazonas, Manaus, n. 397, p. 4, 10 set. 1859

26 Estrella do Amazonas, Manaus, n. 406, p. 2, 22 out. 1859; n. 397, p. 2, 10 set. 1859 
os administradores não se cansavam de apontar que essa rotatividade das turmas de índios era muito prejudicial ao bom andamento dos trabalhos porque, a cada rodada, era preciso reiniciar o treinamento dos trabalhadores em ofícios que, de per si, eram muito especializados. Não faltaram tentativas de estender a permanência dos índios na cidade, mesmo tendo terminado seu tempo de cessão, ou mesmo minorar seu afastamento de casa. Uma delas foi a autorização para que os índios trouxessem suas mulheres, "se eles quiserem", para a cidade durante o tempo em que estivessem engajados. ${ }^{27}$

A menção às fugas sistemáticas dos índios e a obrigatoriedade de seu retorno coloca em relevo os limites da mobilidade de cidadãos que não estavam livres o suficiente para firmar seus contratos e não podiam se ausentar de seus respectivos locais de trabalho sem risco de punição. Salários irrisórios, autonomia comprometida e castigos físicos são elementos em comum a essas pessoas

\section{À guisa de conclusão}

TANTO ÍNDIOS QUANTO AFRICANOS livres vivenciaram os limites de suas liberdades no Brasil do século XIX, na medida em que foram obrigados a realizar trabalhos que não escolheram, a deslocar-se para lugares que não desejavam e impedidos de permanecer onde queriam sem que pudessem recusar-se a nada sob pena de sanção. Ao iluminar tal paradoxo, pretende-se colaborar no adensamento das discussões acerca da chamada transição do trabalho escravo para o trabalho livre no Brasil oitocentista e sobre o fenômeno que tem sido denominado de "precarização da liberdade". ${ }^{28}$

A insegurança não era exclusividade de libertos. Africanos livres e índios também a ela estavam sujeitos. É o que nos mostram os episódios que cercaram o recrutamento de trabalhadores para a olaria do major/deputado Monteiro Tapajós. Foi em 1867, Jeremias, Martinho, Leonel, Maria e Marcelina apareceram nas páginas dos jornais como vítimas da arbitrariedade das autoridades policiais que, com uso da força, os tinha compelido ao trabalho no estabelecimento do dito Tapajós. Os três homens eram africanos livres, a essa altura, já completamente emancipados, que foram retirados de suas ocupações para servir ao deputado por um jornal muito menor do que o que recebiam. Leonel já havia fugido da tal olaria por maus-tratos e, em uma dessas fugas, acabou por se afogar. Maria e Marcelina eram mulheres livres, mas também foram coagidas ao serviço. Quando fugiram, foram caçadas pela polícia e restituídas à olaria de Tapajós. ${ }^{29}$

Manaus não nos revela uma experiência inédita. Em outros lugares do imenso império, africanos livres e índios conviveram de modo estreito e ainda há muito a dizer sobre tais experiências. Um desses casos foi analisado por Danúsia Miranda von Zumben que acompanhou

27 Estrella do Amazonas, Manaus, n. 280, 27 mar. 1858.

28 Ver CHALHOUB, op. cit., 2012.

29 SAMPAIO, op. cit., 2015, p.190-191. 
a trajetória dos africanos nos aldeamentos indígenas no Paraná, entre os anos de 1853 e 1862, em uma experiência onde a noção de "tutela" foi levada ao limite. ${ }^{30}$

Africanos e índios estiveram presentes na maioria das obras públicas de Manaus no século XIX, dividiram muitas coisas, mas, sobretudo, compartilharam a liberdade precária. As experiências aqui descritas se somam a dezenas de outras incluindo o serviço da Companhia de Navegação e Comércio do Amazonas, empresa pertencente ao visconde de Mauá. A rua Brasileira é apenas uma pequena parte da memória desse multiétnico e silenciado mundo do trabalho no norte do Império. ${ }^{31}$

Os africanos livres serão definitivamente emancipados em 1866 e perderemos seus rastros. Em 1892, o igarapé do Espírito Santo foi aterrado como parte das reformas urbanas, sua ponte desapareceu; a Brasileira passou a ser chamada de rua Municipal e, em 1922, transformou-se em 7 de Setembro, nome pelo qual é conhecida no tempo presente. Como via pública, não perdeu sua relevância na cidade. A área onde está a matriz foi tombada pelo IPHAN em 1988.

Quanto a Laudelino, depois de ter conseguido um aumento substantivo de seus jornais em 1861, foi visto tentando vender sua rocinha na Cachoeira Grande em 1865. Parecia passar bem e o anúncio que publicou ainda nos ajuda a lançar luz sobre suas redes de amizades porque os interessados no imóvel deveriam procurar Cesário José de Mesquita, um português relojoeiro e dourador, com oficina estabelecida na rua Oriente (e, talvez, não por coincidência), no térreo da tipografia do jornal onde ele anunciava a venda de seu imóvel. Antes disso, em 1861, um seu requerimento de aumento de salário tinha sido deferido: ele passou a receber 2.000 réis diários e, em troca, era responsável por todas as suas despesas. ${ }^{32}$ As chuvas, definitivamente, já não o incomodavam.

Recebido em: 15/02/2021

Aceito em: 11/03/2021

30 VON ZUNBEN, Danúsia Miranda. Os africanos livres nos aldeamentos indígenas do Paraná provincial (1853-1862). Monografia de Conclusão de Curso (História) - Universidade Federal do Paraná, Curitiba, 2010.

31 Sobre a Companhia de Mauá, ver: BRITO, Roberta Kelly Lima. Vapores de Mauá: a Companhia de Navegação e Comércio do rio Amazonas (1852-1871). Dissertação (Mestrado em História) - Universidade Federal do Amazonas, Manaus, 2018.

32 O Catechista, Manaus, n. 154, p. 3, 25 fev. 1865; Estrella do Amazonas, Manaus, n. 606, p. 4, 28 dez. 1861. 